\title{
14: 103098383-103093192
}

National Cancer Institute

\section{Source}

National Cancer Institute. 14: 103098383-103093192. NCI Thesaurus. Code C41741.

Physical location of BAG5_Gene 